\title{
Preclinical and Clinical Characteristics of the Trichuricidal Drug Oxantel Pamoate and Clinical Development Plans: A Review
}

\author{
Marta S. Palmeirim ${ }^{1,2}$ (1) $\cdot$ Sabine Specht ${ }^{3}$ (1) $\cdot$ Ivan Scandale ${ }^{3}(1) \cdot$ Irene Gander-Meisterernst $^{4} \cdot$ Monika Chabicovsky $^{5}$. \\ Jennifer Keiser ${ }^{1,2}$ (1)
}

Accepted: 17 March 2021 / Published online: 30 April 2021

(c) The Author(s) 2021

\begin{abstract}
Soil-transmitted helminths (Ascaris lumbricoides, hookworm and Trichuris trichiura) infect about one-fifth of the world's population. The currently available drugs are all highly efficacious against A. lumbricoides. However, they are only moderately efficacious against hookworm and poorly efficacious against $T$. trichiura. Oxantel, a tetrahydropyrimidine derivative discovered in the 1970s, has recently been brought back to our attention given its high efficacy against $T$. trichiura infections (estimated $76 \%$ cure rate and $85 \%$ egg reduction rate at a $20 \mathrm{mg} / \mathrm{kg}$ dose). This review summarizes the current knowledge on oxantel pamoate and its use against $T$. trichiura infections in humans. Oxantel pamoate acts locally in the human gastrointestinal tract and binds to the parasite's nicotinic acetylcholine receptor (nAChR), leading to a spastic paralysis of the worm and subsequent expulsion. The drug is metabolically stable, shows low permeability and low systemic bioavailability after oral use. Oxantel pamoate was found to be safe in humans, with only a few mild adverse events reported. Several clinical trials have investigated the efficacy of this drug against $T$. trichiura and suggest that oxantel pamoate is more efficacious against T. trichiura than the currently recommended drugs, which makes it a strong asset to the depleted drug armamentarium and could help delay or even prevent the development of resistance to existing drugs. We highlight existing data to support the use of oxantel pamoate against $T$. trichiura infections.
\end{abstract}

\section{Background}

Soil-transmitted helminths (Ascaris lumbricoides, hookworm and Trichuris trichiura) are the most widespread parasites in the world. They are most common in the poorest regions of the globe where education and access to sanitation and clean water are limited [1]. Soil-transmitted helminthiasis can lead to severe health consequences,

Jennifer Keiser

jennifer.keiser@swisstph.ch

1 Department of Medical Parasitology and Infection Biology, Swiss Tropical and Public Health Institute, P.O. Box, 4002 Basel, Switzerland

2 University of Basel, P.O. Box, 4003 Basel, Switzerland

3 Drugs for Neglected Diseases Initiative, 15 Chemin Louis-Dunant, 1202 Geneva, Switzerland

4 Regulatory Strategies, Schulstrasse 10, 48149 Münster, Germany

5 MC Toxicology Consulting GmbH, Siebensterngasse 31/8, 1070 Vienna, Austria

\section{Key Points}

Oxantel pamoate is a safe and efficacious drug against Trichuris trichiura infections.

Oxantel pamoate is metabolically stable, shows low permeability and low systemic bioavailability after oral use.

The use of this drug in preventive chemotherapy as a combination treatment (e.g. with pyrantel pamoate) could greatly improve the success of this control strategy and prevent or postpone the development of resistance to benzimidazoles.

particularly in children. For example, heavy infections with $T$. trichiura are often associated with chronic irondeficiency anemia, chronic mucoid diarrhea, rectal bleeding, rectal prolapse, and finger clubbing in adults and children. Even mild infections with T. trichiura may be accompanied by growth retardation in children, while 
heavy infections may be linked to severe malnutrition and growth stunting [2].

Currently, the main control strategy used against these intestinal parasites is preventive chemotherapy, i.e. the regular distribution of a single dose of anthelminthic drugs to at-risk groups without prior diagnosis [3]. From 2010 to 2015 , this low-cost strategy averted an estimated $44 \%$ of the disability-adjusted life-years (DALYs) in children [4]. However, the currently used drugs (usually mebendazole and albendazole) are not equally efficacious against all soil-transmitted helminth species [5]. Although these drugs are highly efficacious against A. lumbricoides, resulting in a $10 \%$ decline in its prevalence over the last years, they are only moderately efficacious against hookworm and poorly efficacious against $T$. trichiura [2]. Despite not being used as regularly as the benzimidazoles alone, levamisole, pyrantel pamoate and albendazoleivermectin are also recommended by the World Health Organization (WHO) against soil-transmitted helminths (Table 1) [6]. However, with the exception of albendazole-ivermectin, no monotherapy drugs show acceptable efficacy (i.e. an egg reduction rate (ERR) $>90 \%$ based on the target product profile for drugs to be used for soiltransmitted helminths) when used as a single dose against T. trichiura infections [5, 7].

An alternative anthelminthic compound discovered in the 1970s and known to be highly efficacious against T. trichiura is oxantel pamoate. Oxantel pamoate is a tetrahydropyrimidine derivative (Fig. 1) that has been marketed for veterinary use in non-rodent species for several decades as an oral formulation at single doses of $55 \mathrm{mg} /$ $\mathrm{kg}$ in dogs. Several drugs containing oxantel are currently commercialized by different pharmaceutical companies, for both veterinary and human use (Table 2).

One of the ultimate goals is to register oxantel pamoate for the treatment of T. trichiura infections (for all ages above one year) at a stringent regulatory authority and market it for countries endemic to this parasite. Currently, oxantel pamoate is only approved and marketed for human use in some
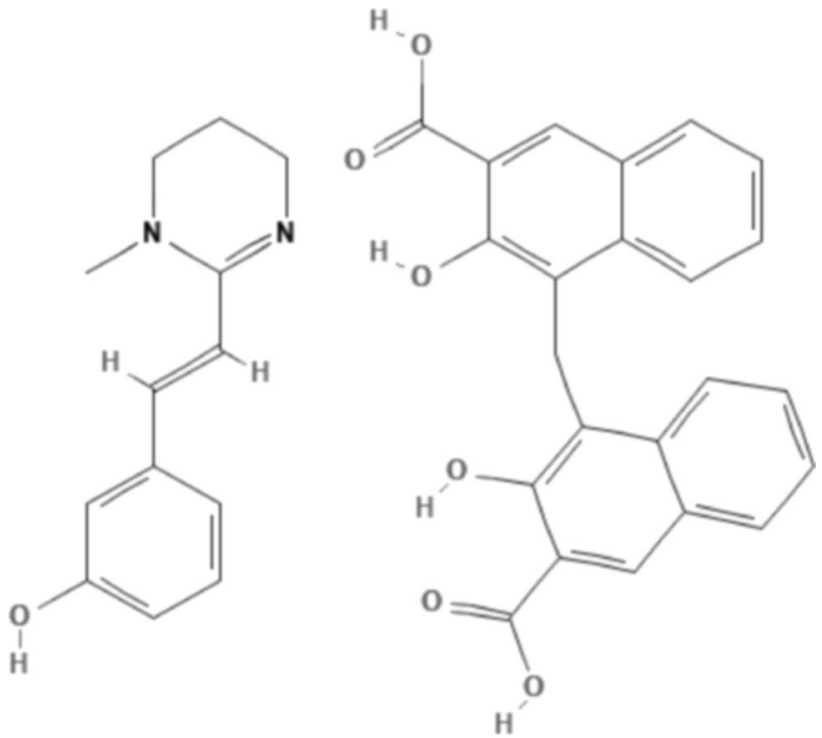

Fig. 1 Structure of oxantel pamoate [9]

countries of South America and Asia for children from six months of age onwards in combination with pyrantel pamoate $\left(\right.$ Quantrel $\left.{ }^{\circledR}\right)$ (Table 2). The European Union funded project "Establishment of a pan-nematode drug development pipeline", Helminth Drug Development Platform (HELP, www.eliminateworms.org) aims to establish a pipeline of anthelminthic drug development candidates. In the framework of HELP, we conducted a thorough review of the available literature to determine if any existing data can be used to support clinical development for T. trichiura. Preclinical data from prior sponsors could unfortunately not be obtained. We also summarize results from key experiments on the binding affinity of oxantel pamoate to the human and rat nAChR, metabolism and intestinal epithelial permeability using Caco-2 cells, which were conducted during this process. Finally, in discussion with regulatory agencies, a clinical development plan has started to be defined.

Table 1 Recommended preventive chemotherapy drugs (single-dose) and their efficacy against soil-transmitted helminth infections

\begin{tabular}{|c|c|c|c|c|c|c|c|}
\hline \multirow[t]{2}{*}{ Treatment } & \multirow[t]{2}{*}{ Mechanism of action } & \multicolumn{2}{|c|}{ Trichuris trichiura } & \multicolumn{2}{|c|}{ Ascaris lumbricoides } & \multicolumn{2}{|c|}{ Hookworm } \\
\hline & & $\mathrm{CR}(\%)$ & $\operatorname{ERR}(\%)$ & $\mathrm{CR}(\%)$ & $\operatorname{ERR}(\%)$ & $\mathrm{CR}(\%)$ & $\operatorname{ERR}(\%)$ \\
\hline ALB & $\beta$-Tubulin binding & 32.1 & 64.3 & 96.5 & 99.7 & 78.5 & 92.2 \\
\hline MEB & $\beta$-Tubulin binding & 44.4 & 80.7 & 96.8 & 99.5 & 41.6 & 65.0 \\
\hline ALB-IVM & ND & 60.0 & 95.5 & 96.7 & 99.9 & 83.7 & 94.7 \\
\hline PP & L-subtype $n A C h R$ agonist & 23.4 & 41.8 & 93.0 & 97.0 & 52.6 & 80.4 \\
\hline LEV & L-subtype nAChR agonist & 28.5 & 62.3 & 97.5 & 91.7 & 14.2 & 65.3 \\
\hline
\end{tabular}

$A L B$ albendazole, $C R$ cure rate, $E R R$ egg reduction rate, $I V M$ ivermectin, $L E V$ levamisole, $M E B$ mebendazole, nAChR, nicotinic acetylcholine receptor, $N D$ not determined, $P P$ pyrantel pamoates

Data from Moser and colleagues [8] 


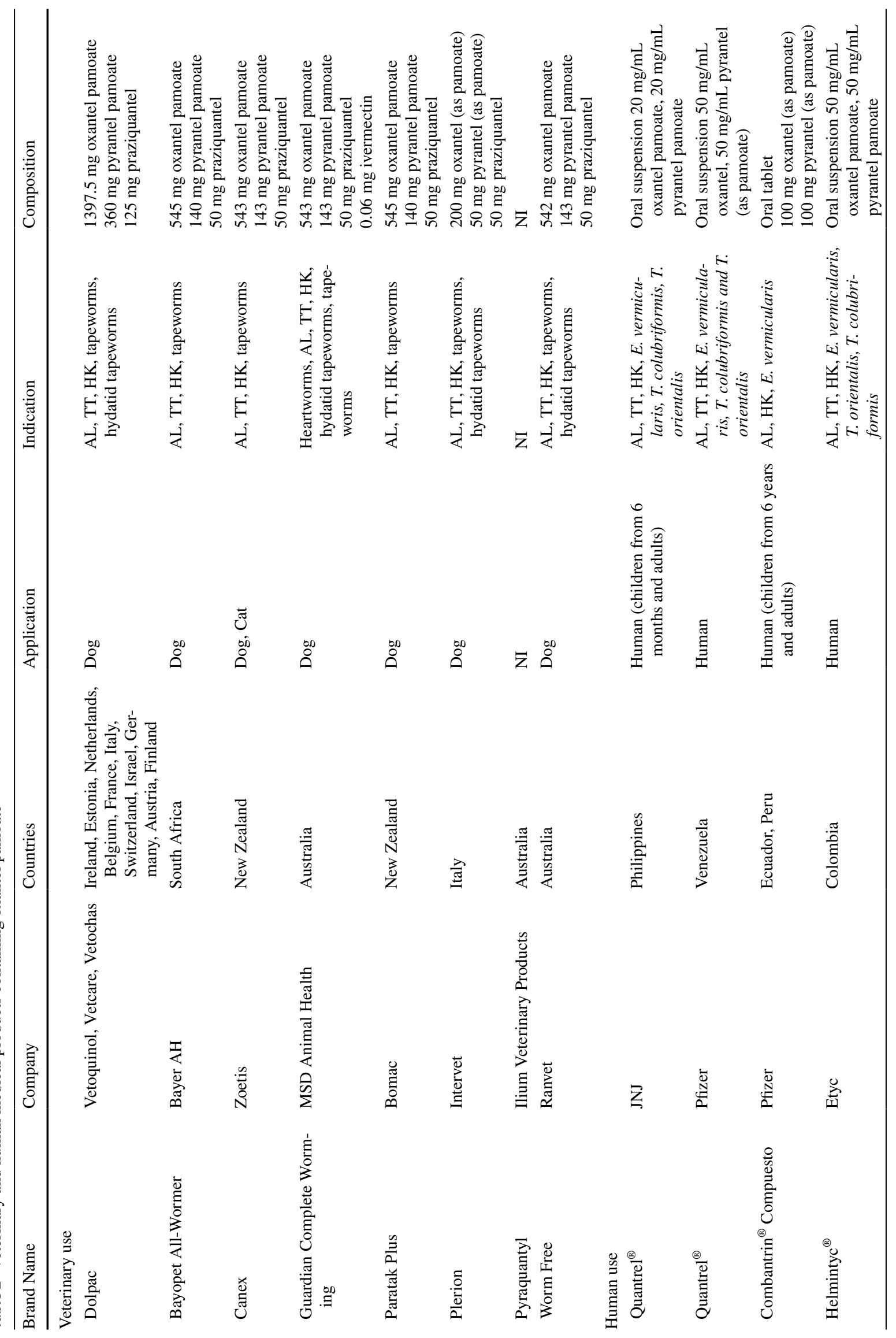




\section{Pharmacology}

\subsection{Pharmacodynamics (PD)}

\subsubsection{Primary Pharmacology}

A study investigating the activity of oxantel pamoate against T. muris, the mouse-specific Trichuris nematode in vitro, reported a half maximal inhibitory concentration $\left(\mathrm{IC}_{50}\right)$ of $2.35 \mu \mathrm{g} / \mathrm{mL}$, corresponding to $3.9 \mu \mathrm{M}$ on L4 larvae (the last stage before the adult stage of Trichuris spp.) following incubation for $72 \mathrm{~h} \mathrm{[10].} \mathrm{In} \mathrm{an} \mathrm{in} \mathrm{vivo} \mathrm{experiment,} \mathrm{differ-}$ ent doses of oxantel pamoate, ranging from 1 to $10 \mathrm{mg} / \mathrm{kg}$, were administered to mice infected with $T$. muris. The oral administration of $10 \mathrm{mg} / \mathrm{kg}$ achieved the highest worm burden reduction (93\%) and worm expulsion rate (88\%) and an $\mathrm{ED}_{50}$ value of $4 \mathrm{mg} / \mathrm{kg}$ was calculated [10], which is significantly lower than the one of other standard anthelminthics [11].

Following oral administration, oxantel pamoate acts locally in the human gastrointestinal tract by binding to the parasite's nicotinic acetylcholine receptor (nAChR; neuronal (N)-type). Nicotinic acetylcholine receptors are widely expressed in the worms' nervous system [12]. These receptors are present both on the neuromuscular junctions on the muscle cells and in the neurons themselves [12]. Oxantel pamoate activates the receptor that leads to an excitatory blockage with subsequent spastic paralysis and expulsion of the worm from the host's gastrointestinal tract. However, the human gastrointestinal tract also has nAChRs that are structurally similar to those of nematodes and undergo similar mechanisms of gating [13]. The main difference lies in the location of these receptors since, in humans, $\mathrm{nAChR}$ is primarily located on intestinal epithelial (Caco-2) and enteric glial cells [13]. Still, the human nAChR could be stimulated by oxantel pamoate as well, which might result in secondary pharmacologic effects.

\subsubsection{Secondary Pharmacology}

In order to reveal the binding affinity of oxantel pamoate to the human and rat $\alpha 7 \mathrm{nAChR}$, an in vitro receptor binding assay was conducted. Experimental details are summarized in Supplementary file 1. Receptors were isolated from human recombinant SH-SY5Y cells and from Wistar rat brain and incubated for 2 or 2.5 hours with oxantel pamoate at concentrations between $0.165 \mathrm{nM}$ and $1.65 \mathrm{mM}$, respectively. Oxantel pamoate was found to bind to the human and rat receptors with $\mathrm{IC}_{50}$ values of $3.48 \mu \mathrm{M}$ and $33.0 \mu \mathrm{M}$, respectively, which is in the same order of the $\mathrm{IC}_{50}$ value of $3.9 \mu \mathrm{M}$ against $T$. muris that was described above. The positive control bungarotoxin showed a higher affinity to both 
human and rat receptors with $\mathrm{IC}_{50}$ values of $1.21 \mathrm{nM}$ and $1.69 \mathrm{nM}$, respectively. However, due to the intended high dose of oral oxantel pamoate treatment $(20 \mathrm{mg} / \mathrm{kg})$, high intestinal concentrations are likely. Thus, local intestinal side effects of treatment with oxantel pamoate, which were already observed in clinical studies, might be due to interactions of oxantel pamoate with the human receptor expressed in the gastrointestinal tract. However, these effects observed in clinical studies were of short duration and reversible. The benefit of the drug seems to predominate potential shortterm reversible adverse events.

\subsection{Pharmacokinetics}

\subsubsection{Absorption and Distribution}

The intestinal epithelial permeability of oxantel pamoate was investigated in an in vitro assay using Caco- 2 cells (Supplementary file 2). Oxantel pamoate at a concentration of $10 \mu \mathrm{M}$ was incubated with Caco- 2 cells for $60 \mathrm{~min}$ at $37^{\circ} \mathrm{C}$. Four reference compounds with known high (propranolol, labetalol), moderate (ranitidine) and low (colchicine) intestinal permeability were incubated under the same conditions. With a mean apical to basolateral and basolateral to apical permeability of 0.2 and $0.4 \times 10^{-6} \mathrm{~cm} / \mathrm{s}$, respectively, the permeability of oxantel pamoate was in the same range as

Table 3 Permeability of oxantel pamoate in Caco- 2 cells

\begin{tabular}{llll}
\hline Compound & $\begin{array}{l}\text { Mean A-B per- } \\
\text { meability }\left(10^{-6}\right. \\
\mathrm{cm} / \mathrm{s})\end{array}$ & $\begin{array}{l}\text { Mean B-A per- } \\
\text { meability }\left(10^{-6}\right. \\
\mathrm{cm} / \mathrm{s})\end{array}$ & $\begin{array}{l}\text { Mean } \\
\text { recovery } \\
(\%)\end{array}$ \\
\hline Oxantel pamoate & 0.2 & 0.4 & $85-89$ \\
Colchicine & 0.3 & 4.0 & $71-72$ \\
Labetalol & 5.1 & 34.1 & $84-99$ \\
Propranolol & 26.3 & 21.5 & $88-96$ \\
Ranitidine & 0.8 & 2.2 & $83-95$ \\
\hline
\end{tabular}

$A-B$ apical to basolateral, $B-A$ basolateral to apical colchicine and is, therefore, considered of low permeability in vitro (Table 3 ).

The low gastrointestinal absorption of oxantel pamoate was confirmed in a non-GLP (Good Laboratory Practice) study in rats. A single dose of $100 \mathrm{mg} / \mathrm{kg}$ oxantel pamoate was applied (together with $100 \mathrm{mg} / \mathrm{kg}$ albendazole). Blood samples were taken $0.25,0.5,1,2,4,6,8,10,24$, and 33 hours post-treatment. At all time points, plasma levels of oxantel pamoate were below a lower limit of quantification (LLOQ) of $0.4 \mu \mathrm{g} / \mathrm{mL}(=0.66 \mu \mathrm{M})$. This accounts for a bioavailability of $<0.025 \%$, based on the assumption that the entire dose applied $(100 \mathrm{mg} / \mathrm{kg}$ ) would be absorbed and not metabolized, based on an average blood volume of 16 $\mathrm{mL}$ and a body weight of $250 \mathrm{~g}$ per rat [14]. Also, according to the core data sheet for Quantrel ${ }^{\circledR}$, oxantel pamoate is poorly absorbed in the gastrointestinal tract because of its low aqueous solubility. It is stated that only around 8 to $10 \%$ is absorbed following a single dose of $10 \mathrm{mg} /$ person and $0.5-1.8 \%$ at dose levels of $50 \mathrm{mg} / \mathrm{kg}$; however, the underlying data could not be obtained [15]. Further pharmacokinetic (PK) studies will be embedded in the planned Phase I study (Box 1).

\subsubsection{Metabolism and Excretion}

The metabolic stability was evaluated by incubating oxantel pamoate and reference compounds (midazolam, propranolol and terfenadine) at a respective concentration of $0.1 \mu \mathrm{M}$ with human and rat intestinal microsomes $(0.1 \mathrm{mg} / \mathrm{mL})$ for 0,30 , 60, 90 and 120 min (experimental details are summarized in Supplementary file 3). Following incubations of oxantel pamoate with either rat or human intestinal microsomes up to 120 min, oxantel pamoate was considered metabolically stable with a calculated mean half-life of over $120 \mathrm{~min}$ in both rat and human intestinal microsomes (Table 4).

Since oxantel pamoate was found to be metabolically stable, only a very low intestinal permeability was observed in vitro and low oral bioavailability is expected; therefore, the investigation of hepatic metabolism was not considered
Box 1 Suggested clinical development plan for oxantel pamoate
1) A two-week repeated dose toxicity study including PK and local tolerability and reversibility of findings (if any)

2) In vitro and in vivo genotoxicity testing

3) One regulatory compliant Phase $1 \mathrm{~b}$ study comparing single administration on one day versus single administration on three consecutive days with PK/PD in T. trichiura-positive patients

4) One regulatory compliant Phase 3 study in T. trichiura-positive patients with mild to severe disease in comparison to mebendazole. 
applicable. It is assumed, that oxantel pamoate acts locally in the gastrointestinal tract following oral administration and is excreted unchanged via feces.

\subsubsection{Pharmacokinetic Drug Interactions}

The inhibition of cytochrome (CYP) enzymes by oxantel pamoate has been investigated in two published in vitro studies [14, 16]. Oxantel pamoate did not inhibit CYP1A2, CYP2C19 and CYP3A4 $\left(\mathrm{IC}_{50}>100 \mu \mathrm{M}\right)$ [14]. CYP2C9 and CYP2D6 were moderately inhibited by oxantel pamoate $\left(\mathrm{IC}_{50}=7.8 \mu \mathrm{M}\right.$ and CYP2D6) [14]. In the second study, oxantel pamoate showed an inhibitory activity against CYP2C9 and CYP2D6 [16]. The inhibition of CYP1A2, CYP2C19, and CYP3A4 by oxantel pamoate was more pronounced than in a previous study by Cowan et al [14], which reported no interaction of oxantel pamoate with these enzymes. Overall, the risk for systemic drug-drug interaction is considered low due to the intended treatment schedule and low exposure.

\subsection{Toxicity}

Concerning single-dose toxicity, Marchiondo reported that oxantel pamoate was well tolerated in acute toxicity studies with median lethal dose $\left(\mathrm{LD}_{50}\right)$ values of 300,980 and 3200 $\mathrm{mg} / \mathrm{kg}$ in mice, rats and rabbits, respectively [17]. Repeateddose toxicity testing in rats will need to be conducted to explore any potential risk related to repeated administrations in humans and to examine the reversibility of findings, if any (Box 1). Local effects on the gastrointestinal tract will be explored in this 14-day repeated dose toxicity study in rats (Box 1). Since there are no published studies allowing for the definition of the genotoxicity risk, in vitro and in vivo testing will need to be conducted according to current regulatory requirements.

If a lack of biologically relevant systemic exposure is confirmed in the planned repeated-dose toxicity study in rats and the Phase I study, studies concerning reproductive and developmental toxicity, as well as phototoxicity, are not planned and are not considered to add value to the program. This also considers animal ethics. Carcinogenicity studies are not required considering the short oxantel pamoate treatment duration of a maximum of three days.

\section{Clinical Efficacy}

A PubMed search identified 15 studies, 11 of which were clinical trials assessing the efficacy of at least one treatment arm including oxantel pamoate alone or in combination with other drugs against $T$. trichiura. From the references of these 11 studies, another 14 were identified and will be mentioned in this review. The characteristics of each of these 25 studies are presented in Table 5. Only studies with a follow-up period between two and six weeks after treatment are listed.

The studies assessing the efficacy and safety of oxantel pamoate were conducted in two phases; the first phase took place in the 1970s followed by the second, which took place after the year 2000 with studies conducted by Swiss Tropical and Public Health Institute researchers. The earliest studies were performed in Asian countries and most had relatively small sample sizes, with the exception of the study by Lim and colleagues, which had a larger sample size [18]. Most studies were conducted with children and the most common diagnostic method was the Kato-Katz technique. It is likely that differences in infection intensity, as well as the different diagnostic methods used in the different studies (e.g. Kato Katz, formol-ether, Stoll) have an impact on the observed cure rates (CRs) and egg reduction rates (ERRs) [19, 20].

\subsection{Trichuris trichiura Infections}

Despite having relatively low sample sizes, the first trials using oxantel pamoate (sometimes in combination with

Table 4 Intrinsic stability of oxantel pamoate in rat and human intestinal microsomes

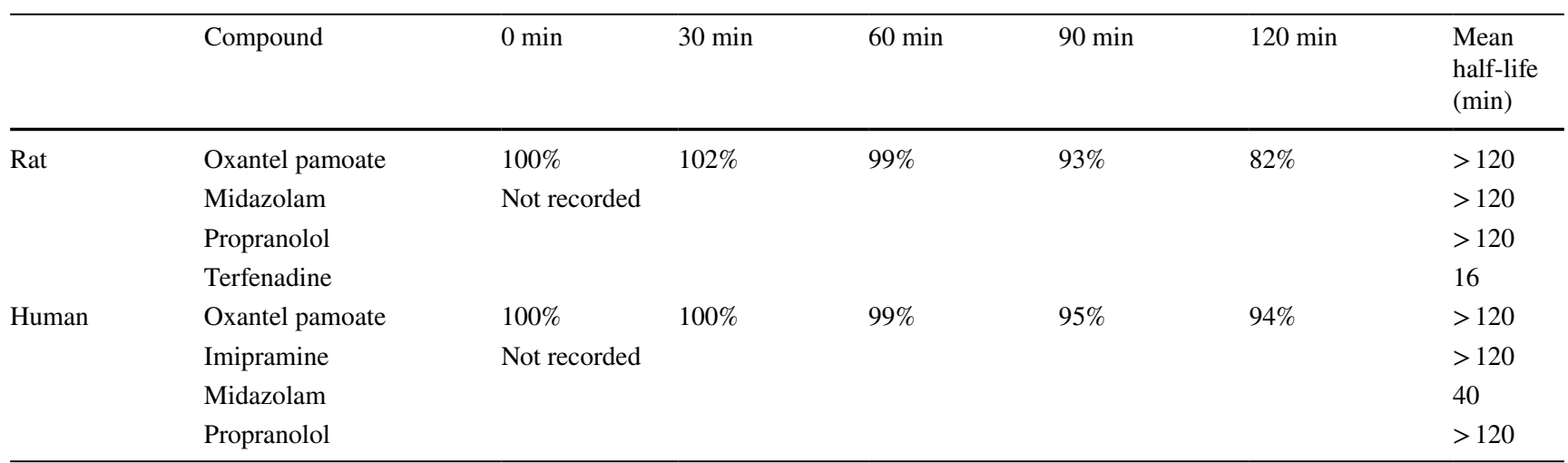


Table 5 Characteristics of the clinical trials including oxantel pamoate in at least one treatment arm

\begin{tabular}{|c|c|c|c|c|c|c|}
\hline Ref & Year & Follow-up sampling (time after treatment) & Diagnostic techniques & $N$ & Age group & Location \\
\hline [21] & 1974 & 22 days & Kato-Katz & 64 & NR & South Korea \\
\hline [22] & 1975 & 10th and 22nd day & Stoll and formalin-ether sedimentation & 56 & $6-68$ & South Korea \\
\hline [23] & 1975 & 10 days & Kato-Katz & 104 & $11-13$ & Malaysia \\
\hline [24] & 1977 & 3 weeks & Kato-Katz and Stoll & 34 & Orphanage children & South Korea \\
\hline [25] & 1978 & 22 days & Kato-Katz and Stoll & 60 & Children & South Korea \\
\hline [26] & 1978 & 10th and 22nd day & $\begin{array}{l}\text { Kato-Katz, Stoll and acid-ether concentra- } \\
\text { tion }\end{array}$ & 32 & Elementary school & Philippines \\
\hline [18] & 1978 & 10th and 22nd day & $\begin{array}{l}\text { Kato-Katz, Stoll and formalin-ether sedi- } \\
\text { mentation }\end{array}$ & 704 & $2-68$ & South Korea \\
\hline [27] & 1978 & 10-12 days, 20-26 days & $\begin{array}{l}\text { Beaver egg count and brine-flotation } \\
\text { method }\end{array}$ & 66 & $7-11$ & Malaysia \\
\hline [28] & 1978 & 10 or 11 th and 20 or 21 st day & $\begin{array}{l}\text { Stoll, formalin-ether sedimentation and } \\
\text { coproculture (hookworm) }\end{array}$ & 45 & All age groups & South Korea \\
\hline [29] & 1978 & 10-20 days & Formalin-ethic concentration & 193 & 1 to $>55$ & Philippines \\
\hline [30] & 1979 & 3-4 weeks & Stoll & 150 & NR & South Korea \\
\hline [31] & 1980 & $10-15$ days, $20-25$ days & $\begin{array}{l}\text { Kato-Katz and/or formalin-ether concentra- } \\
\text { tion }\end{array}$ & 71 & $0-\mathrm{NR}$ & Philippines \\
\hline [32] & 1980 & Days 14,21 and 28 & Formalin-ether and direct smear & 51 & $16-67$ & Malaysia \\
\hline [33] & 1981 & 3 weeks & Salt flotation and Beaver egg count & 472 & $6-12$ & Malaysia \\
\hline [34] & 1981 & 4 weeks & NR & 28 & $0-69$ & South Korea \\
\hline [35] & 1982 & 14-21 days & Formalin-ether & 24 & $1-60$ & Finland \\
\hline [36] & 1984 & 3 weeks & $\begin{array}{l}\text { Formal-ether sedimentation and Bearer's } \\
\text { direct smear }\end{array}$ & 201 & $6-13$ & Malaysia \\
\hline [37] & 1992 & 2 weeks, 4 weeks & Kato-Katz and tube hatching for hookworm & 327 & NR & China \\
\hline [38] & 2002 & 21-24 days & Kato-Katz & 1329 & $6-9$ & Tanzania \\
\hline [39] & 2014 & 18-23 days & Kato-Katz & 480 & $6-14$ & Tanzania \\
\hline [40] & 2015 & 18-23 days & Kato-Katz & 431 & $6-14$ & Tanzania \\
\hline [41] & 2016 & 20-26 days & Kato-Katz & 349 & $6-14$ & Tanzania \\
\hline [42] & 2017 & 14-21 days & Kato-Katz & 601 & $15-18$ & Côte d'Ivoire \\
\hline [43] & 2018 & 14-21 days & Kato-Katz & 611 & $12-18$ & Tanzania \\
\hline [44] & 2018 & 17-30 days & Kato-Katz & 414 & $6-15$ & Laos \\
\hline
\end{tabular}

$N A$ not applicable, $N R$ not reported, $N$ sample size (number of participants infected with $T$. trichiura in each treatment arm)

pyrantel pamoate) already suggested a high efficacy of oxantel pamoate against $T$. trichiura (Table 6). All 17 studies conducted in the 1970s and early 1980s reported on the efficacy using CRs and, in most cases, ERRs; CRs ranged from $29 \%$ (with a single dose of oxantel, $10-20 \mathrm{mg} / \mathrm{kg}$ ) to $100 \%$ (with $20 \mathrm{mg} / \mathrm{kg}$ of oxantel-pyrantel once per day for 2 days).

Several years later, a series of clinical trials testing oxantel pamoate alone and in combination with other drugs were conducted in Lao People's Democratic Republic (PDR), Côte d'Ivoire and Pemba Island, Tanzania [38-44] (Table 6). In these trials, the treatment arms with the highest efficacy against $T$. trichiura all included oxantel pamoate with ERRs reaching up to $100 \%$, showing that this drug is clearly superior to most available drugs. However, CRs varied considerably among studies.
In a dose-ranging study, Moser and colleagues identified $5 \mathrm{mg} / \mathrm{kg}$ as the minimum effective dose and $22 \mathrm{mg} / \mathrm{kg}$ was modelled as the maximum effective dose [41]. A weight-independent dose of $500 \mathrm{mg}$ oxantel pamoate for sub-Saharan African children was proposed by the authors. With this dose, 95\% of sub-Saharan African school-aged children would receive a minimum of $11.7 \mathrm{mg} / \mathrm{kg}$ and a maximum of $32.0 \mathrm{mg} / \mathrm{kg}$ oxantel pamoate [41].

A recent network meta-analysis based on data from six randomized controlled studies confirmed the high efficacy of oxantel pamoate against $T$. trichiura [8]. The authors found that a $20 \mathrm{mg} / \mathrm{kg}$ single dose of oxantel pamoate resulted in a significantly higher CR $(76 \%)$ and ERR $(85 \%)$ than the monotherapies of albendazole, pyrantel pamoate and tribendimidine. 
Table 6 Trichuris trichiura cure rates (\%, CRs) and egg reduction rates (\%, ERRs) resulting from all the treatment arms of clinical trials testing the efficacy of oxantel pamoate either alone or in combination with other drugs. The treatment arms were ranked from the highest to lowest CR

\begin{tabular}{|c|c|c|c|c|c|c|c|}
\hline Ref & Year & Drugs and corresponding doses & Regimen & Formulation & $\mathbf{N}$ & CR (\%) & $\operatorname{ERR}(\%)$ \\
\hline [44] & 2018 & OXP $20 \mathrm{mg} / \mathrm{kg}+\mathrm{ALB}$ & Single dose & Tablet & 138 & 100 & 100 \\
\hline [25] & 1978 & OXP-PP 20 mg/kg & qd, 2 days & Suspension & 10 & 100 & 100 \\
\hline [23] & 1975 & OXP $10 \mathrm{mg} / \mathrm{kg}$ & qd, 3 days & NR & 33 & 100 & 100 \\
\hline [35] & 1982 & OXP+PP 150 mg/tablet, 20 mg/kg & Single dose & Tablet & 117 & 98 & NR \\
\hline [31] & 1980 & OXP-PP $15 \mathrm{mg} / \mathrm{kg}$ & bid, 1 day & NR & 34 & 94 & 99 \\
\hline [44] & 2018 & OXP $20 \mathrm{mg} / \mathrm{kg}+\mathrm{PP} 20 \mathrm{mg} / \mathrm{kg}+\mathrm{ALB}$ & Single dose & Tablet & 138 & 93 & 100 \\
\hline [18] & 1978 & OXP $20 \mathrm{mg} / \mathrm{kg}$ & Single dose & Syrup & 15 & 93 & 100 \\
\hline [37] & 1992 & OXP-PP $150 \mathrm{mg}$ & bid, 2 days & Tablet & 56 & 92 & 98 \\
\hline [24] & 1977 & OXP+PP 125 mg/tablet, 15 mg/kg & Single dose & Tablet & 22 & 91 & 96 \\
\hline [21] & 1974 & OXP $10 \mathrm{mg} / \mathrm{kg}$ & Single dose & Suspension & 64 & 91 & 95 \\
\hline [25] & 1978 & OXP-PP 15 mg/kg & Single dose & Suspension & 10 & 90 & 100 \\
\hline [25] & 1978 & OXP-PP $15 \mathrm{mg} / \mathrm{kg}$ & qd, 2 days & Suspension & 10 & 90 & 100 \\
\hline [18] & 1978 & OXP $15 \mathrm{mg} / \mathrm{kg}$ & Single dose & Syrup & 50 & 90 & 91 \\
\hline [18] & 1978 & OXP-PP $15 \mathrm{mg} / \mathrm{kg}$ & Single dose & Syrup & 10 & 90 & 100 \\
\hline [44] & 2018 & OXP $20 \mathrm{mg} / \mathrm{kg}+$ PP $20 \mathrm{mg} / \mathrm{kg}+$ MEB $500 \mathrm{mg}$ & Single dose & Tablet & 69 & 89 & 99 \\
\hline [29] & 1978 & OXP $15 \mathrm{mg} / \mathrm{kg}$ & bid, 1 day & NR & 37 & 89 & NR \\
\hline [23] & 1975 & OXP $15 \mathrm{mg} / \mathrm{kg}$ & Single dose & NR & 34 & 88 & 96 \\
\hline [30] & 1979 & OXP $15 \mathrm{mg} / \mathrm{kg}$ & Single dose & Suspension & 49 & 86 & 93 \\
\hline [24] & 1977 & OXP+PP $100 \mathrm{mg} /$ tablet, $15 \mathrm{mg} / \mathrm{kg}$ & Single dose & Tablet & 34 & 85 & 97 \\
\hline [31] & 1980 & OXP-PP 20 mg/kg & Single dose & NR & 37 & 84 & 97 \\
\hline [32] & 1980 & OXP+PYR $20 \mathrm{ml}$ & Single dose & Suspension & 51 & 84 & 99 \\
\hline [26] & 1978 & OXP-PP 15 to $20 \mathrm{mg} / \mathrm{kg}$ & qd, 3 days & Tablet & 32 & 84 & 98 \\
\hline [18] & 1978 & OXP $10-15 \mathrm{mg} / \mathrm{kg}$ & Single dose & Tablet & 193 & 84 & 97 \\
\hline [43] & 2018 & OXP $25 \mathrm{mg} / \mathrm{kg}+\mathrm{ALB}$ & Single dose & Tablet & 220 & 83 & 100 \\
\hline [42] & 2017 & OXP $25 \mathrm{mg} / \mathrm{kg}+\mathrm{ALB}$ & Single dose & Tablet & 148 & 83 & 100 \\
\hline [33] & 1981 & OXP-PP 10 mg/kg & $\mathrm{qd}, 3$ days & Tablet & 48 & 79 & 95 \\
\hline [18] & 1978 & OXP-PP $15-20 \mathrm{mg} / \mathrm{kg}$ & Single dose & Tablet & 78 & 78 & 95 \\
\hline [18] & 1978 & OXP-PP $10 \mathrm{mg} / \mathrm{kg}$ & Single dose & Syrup & 80 & 77 & 81 \\
\hline [30] & 1979 & OXP-PP 20 mg/kg & Single dose & Tablet & 24 & 75 & 98 \\
\hline [18] & 1978 & OXP $25 \mathrm{mg} / \mathrm{kg}$ & Single dose & Syrup & 12 & 75 & 96 \\
\hline [44] & 2018 & OXP $20 \mathrm{mg} / \mathrm{kg}+\mathrm{PP} 20 \mathrm{mg} / \mathrm{kg}$ & Single dose & Tablet & 69 & 74 & 98 \\
\hline [22] & 1975 & OXP $10 \mathrm{mg} / \mathrm{kg}$ & Single dose & Suspension & 56 & 73 & 92 \\
\hline [34] & 1978 & OXP+PYR (100 mg/tablet) 20 mg/kg & Single dose & Tablet & 45 & 71 & 91 \\
\hline [25] & 1978 & OXP-PP $20 \mathrm{mg} / \mathrm{kg}$ & Single dose & Suspension & 10 & 70 & 72 \\
\hline [40] & 2015 & OXP $20 \mathrm{mg} / \mathrm{kg}+\mathrm{ALB}$ & Single dose & Tablet & 108 & 69 & 99 \\
\hline [27] & 1978 & OXP $10-20 \mathrm{mg} / \mathrm{kg}$ & qd, 3 days & Suspension & 24 & 67 & 95 \\
\hline [42] & 2017 & OXP 25 mg/kg + TRIB 400 mg & Single dose & Tablet & 148 & 66 & 100 \\
\hline [23] & 1975 & $\mathrm{OXP} 10 \mathrm{mg} / \mathrm{kg}$ & Single dose & NR & 37 & 65 & 90 \\
\hline [18] & 1978 & OXP $10 \mathrm{mg} / \mathrm{kg}$ & Single dose & Syrup & 266 & 64 & 90 \\
\hline [41] & 2016 & OXP $25 \mathrm{mg} / \mathrm{kg}$ & Single dose & Tablet & 50 & 60 & 98 \\
\hline [36] & 1984 & OXP+PP $15 \mathrm{mg} / \mathrm{kg}$ & Single dose & NR & 201 & 60 & 85 \\
\hline [41] & 2016 & OXP $30 \mathrm{mg} / \mathrm{kg}$ & Single dose & Tablet & 50 & 59 & 99 \\
\hline [34] & 1981 & OXP+PP, 75 mg/tablet, 10 mg/kg & Single dose & Tablet & 33 & 55 & 86 \\
\hline [29] & 1978 & OXP $15 \mathrm{mg} / \mathrm{kg}$ & Single dose & NR & 193 & 53 & NR \\
\hline [41] & 2016 & OXP $20 \mathrm{mg} / \mathrm{kg}$ & Single dose & Tablet & 50 & 50 & 98 \\
\hline [41] & 2016 & OXP 15 mg/kg & Single dose & Tablet & 51 & 49 & 97 \\
\hline [33] & 1981 & OXP-PP 10 mg/kg & Single dose & Tablet & 84 & 48 & 86 \\
\hline [38] & 2002 & OXP-PP 10 mg/kg & Single dose & Tablet & 440 & 38 & 87 \\
\hline [39] & 2014 & OXP $20 \mathrm{mg} / \mathrm{kg}+\mathrm{ALB}$ & Single dose & Tablet & 119 & 31 & 96 \\
\hline [27] & 1978 & OXP $10-20 \mathrm{mg} / \mathrm{kg}$ & Single dose & Suspension & 17 & 29 & 97 \\
\hline [39] & 2014 & OXP 20 mg/kg & Single dose & Tablet & 121 & 26 & 93 \\
\hline [41] & 2016 & OXP 5 mg/kg & Single dose & Tablet & 48 & 22 & 85 \\
\hline [41] & 2016 & OXP $10 \mathrm{mg} / \mathrm{kg}$ & Single dose & Tablet & 51 & 22 & 86 \\
\hline
\end{tabular}

$A L B$ albendazole, bid twice per day, $C R$ cure rate, $E R R$ egg reduction rate, $I V M$ ivermectin, $L E V$ levamisole, $N$ sample size; $N R$ not reported, $M E B$ mebendazole, $P P$ pyrantel pamoate, $q d$ once per day. Two studies [31,37] had two follow-up time points; in this table we present the CR and ERR for the second time point only (4 weeks and 25 days, respectively)

\subsection{Ascaris lumbricoides and Hookworm Infections}

Despite its high efficacy against $T$. trichiura, laboratory studies [10] and clinical trials found a wide range of efficacy of oxantel pamoate for the other two soil-transmitted helminths. For A. lumbricoides, CRs ranged from 2 to $100 \%$ and for hookworm from 10 to $100 \%$. Of note, the highest efficacies were reported by the oldest studies. On the other 
hand, the dose-ranging study conducted by Moser and colleagues revealed a low efficacy of oxantel pamoate against A. lumbricoides and hookworm [41]. However, when combined with albendazole, mebendazole, pyrantel pamoate, or tribendimidine, the efficacy of oxantel pamoate against these two parasites increased considerably, reaching up to $100 \%$ CR and $100 \%$ ERR $[42,44]$.

\section{Clinical Safety}

Side effects of the administration of oxantel pamoate are believed to be due to interactions between oxantel pamoate and the human nAChRs located in intestinal cells. Only a few of the studies from the 1970/80s reported side effects from a single dose of oxantel pamoate (Table 7). Clinical trials implemented after the year 2000 reported adverse events in more detail, presenting the number and proportion of adverse events by treatment arm. These studies found that oxantel pamoate was well tolerated by participants, with adverse events being mild to moderate. The frequency of adverse events seemed to be independent of the oxantel pamoate dose [41]. In many cases, participants already suffered from the same adverse events prior to treatment. No serious adverse event or death was ever reported. In all clinical trials, the most common adverse events were stomach pain and headache.

Only four studies administered more than one dose of oxantel pamoate, either $10 \mathrm{mg} / \mathrm{kg}$ once per day for three days alone or in combination with pyrantel pamoate [33, 45 ] or $15-20 \mathrm{mg} / \mathrm{kg}$ once per day for three days in combination with pyrantel pamoate [26]. Of these, only Garcia and colleagues reported to have one participant (3\%) with an adverse event; no other studies reported adverse events in treatment arms with oxantel pamoate.

Also, according to Quantrel ${ }^{\circledR}$ (oxantel pamoate-pyrantel pamoate) package information leaflet, it is extremely well tolerated and side effects, if encountered, usually relate to the gastrointestinal tract. All adverse drug reactions identified during the post-marketing experience of Quantrel ${ }^{\circledR}$, such as decreased appetite, insomnia, dizziness, somnolence, headache, abdominal pain, diarrhea, nausea, vomiting, cold sweat, hyperhidrosis, rash, pruritus and urticarial, were very rare (less than one case per 10,000).
Quantrel ${ }^{\circledR}$ is marketed for children who have 6 months of age or more. Although the absorption is known to be influenced by physiologic properties such as gastrointestinal fluid composition and volume, transit time, morphology, microbiota, and drug metabolizing enzymes, none of these properties differed much between one-year-old children and adults [46]. Therefore, no considerable difference regarding gastrointestinal absorption of oxantel pamoate is expected. Additionally, because no biologically relevant systemic exposure is assumed following oral application, although a role in organ development of nAChRs cannot be excluded based on the ubiquitous expression profile of nAChRs, substantial effects from acute oral dosing (1-3 days) of the drug on developing organs are considered unlikely in children aged one year and older.

Animal reproductive studies have found no teratogenic effects of oxantel pamoate. However, no well-controlled trials assessed the effect of oxantel pamoate in pregnant or lactating women $[47,48]$. Therefore, breastfeeding should be discontinued if oxantel pamoate is administrated to the mother and the risk benefit needs to be carefully assessed before administering the drug to a pregnant woman [49].

\section{Conclusions}

Our review highlights that oxantel pamoate is, unlike the currently approved drugs, an excellent drug for treating T. trichiura infections. Oxantel pamoate has also been shown to be a safe drug that is already being used in children aged $>6$ months. Thus, we believe that this drug would be a very important addition to the depleted drug armamentarium, not only because of its high efficacy, but also because it can contribute to delaying or even preventing development of resistance to the currently available treatment options. While reviewing the literature and preparing the briefing book prior to discussions with regulatory authorities we identified additional studies, which are summarized in this review (Box 1). Efforts will continue in the framework of HELP to fill the remaining knowledge gaps so that oxantel pamoate can be available for treatment of $T$. trichiura infections in the near future. 


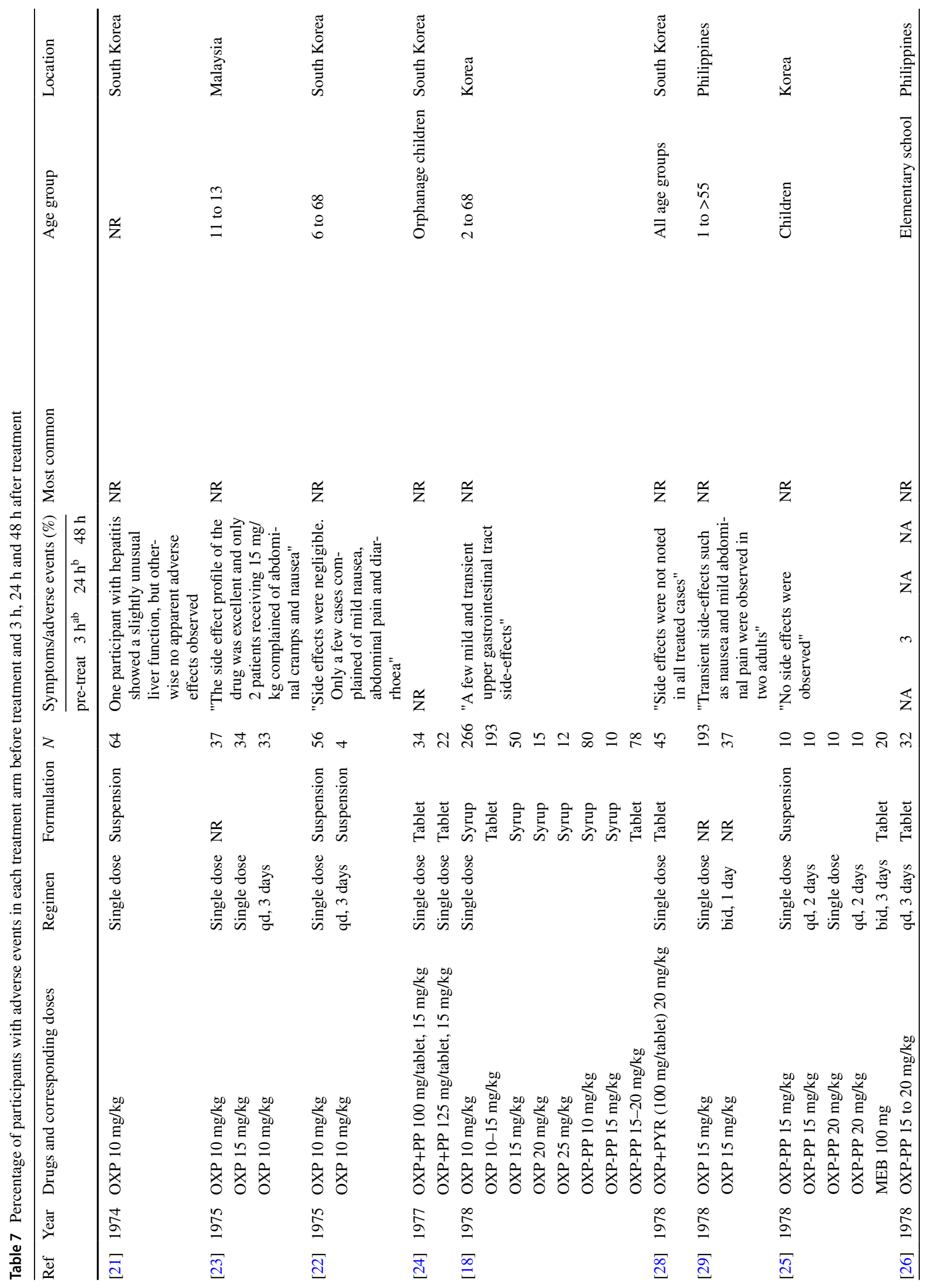




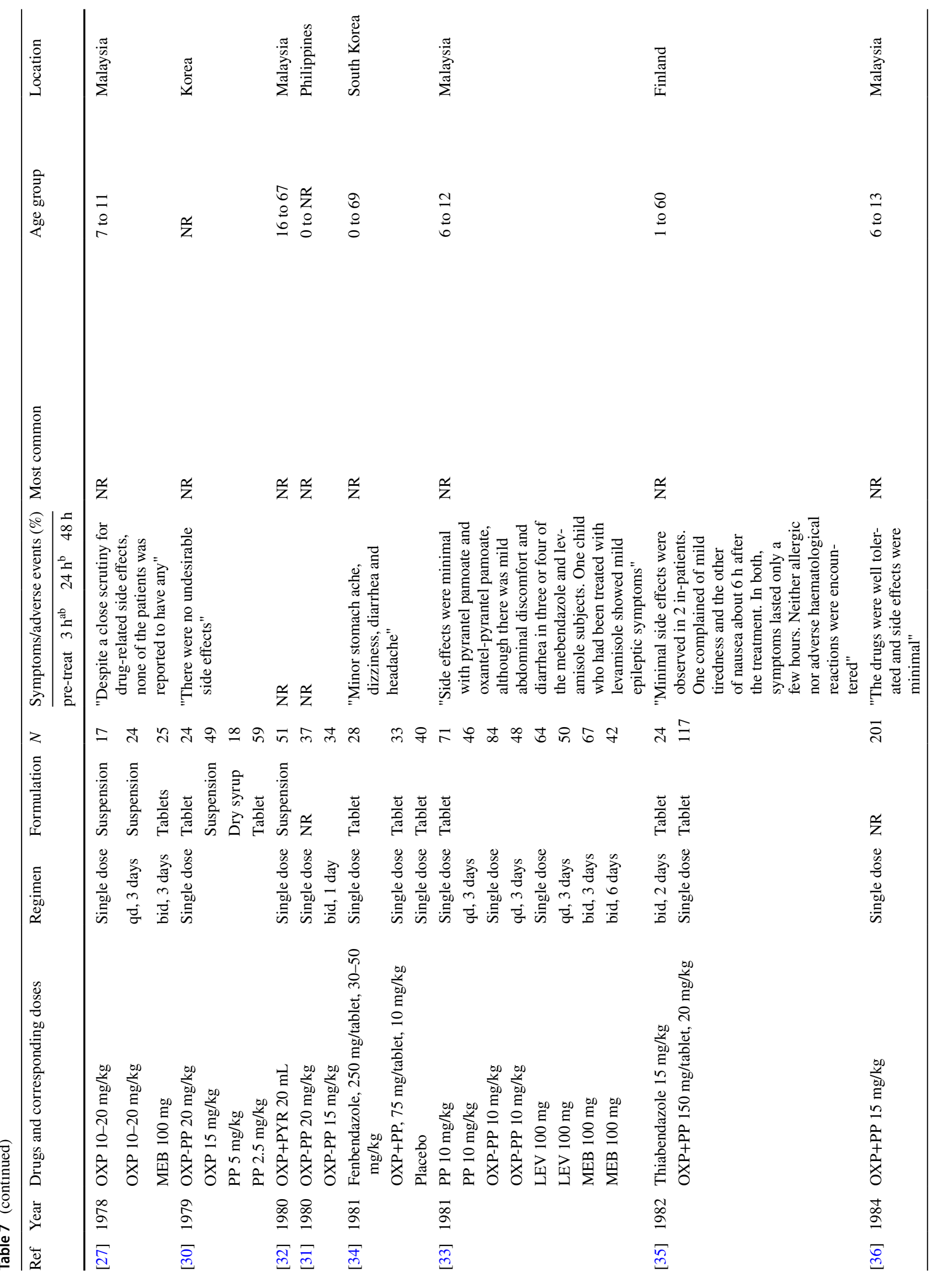




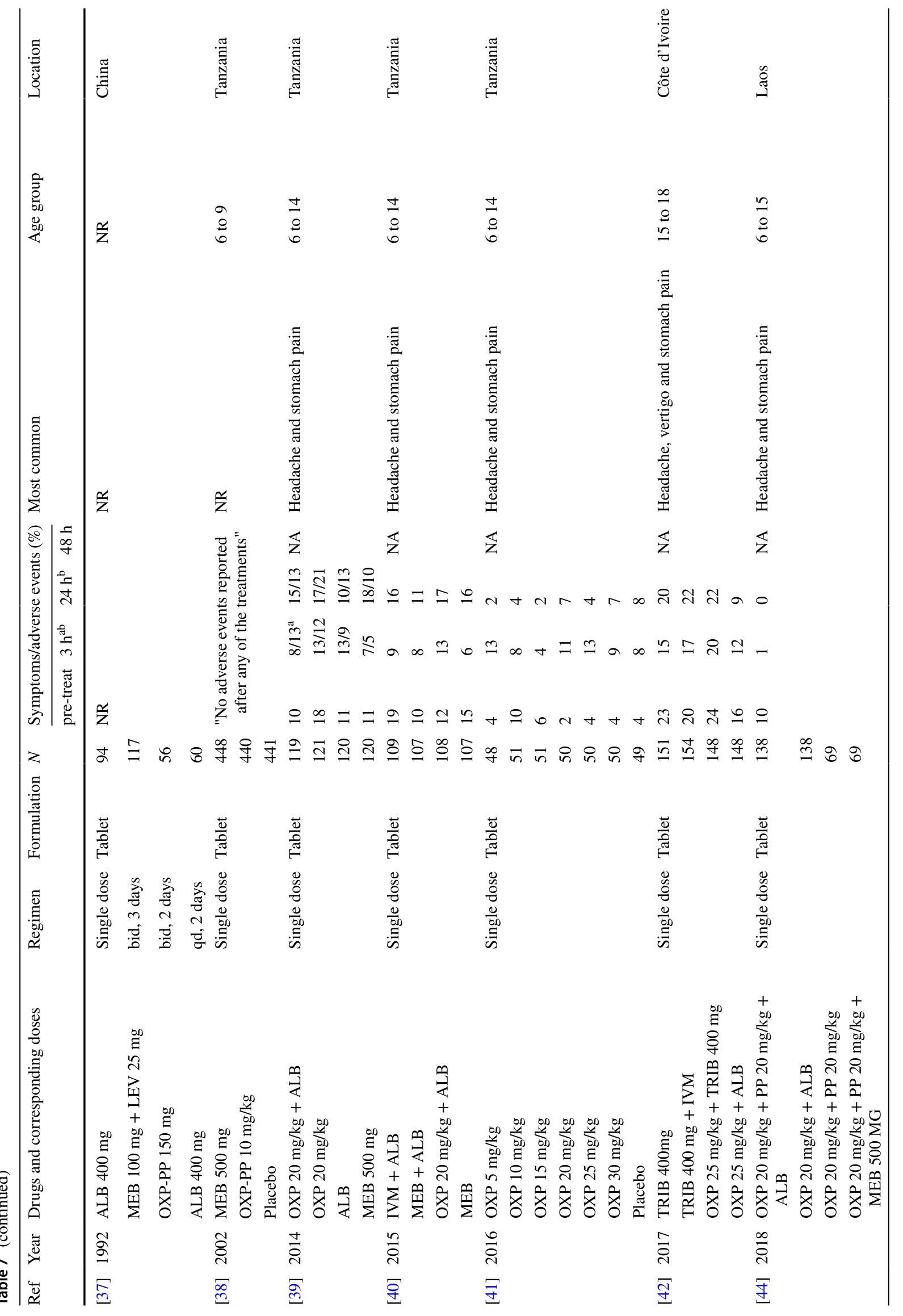


Supplementary Information The online version contains supplementary material available at https://doi.org/10.1007/s40265-021-01505-1.

Acknowledgements We would like to thank the European Union Horizon 2020 Grant Agreement No. 815628 for financial support.

\section{Declarations}

Funding Open Access funding provided by Universität Basel (Universitätsbibliothek Basel). This study was supported by European Union Horizon 2020 (HELP, No. 815628). The funder of the study had no role in the study design, data collection, data analysis, data interpretation, or writing of the report. The corresponding author had full access to all the data in the study and had final responsibility for the decision to submit for publication.

Conflict of interest The authors declare that there is no conflict of interest.

Availability of data and material All underlying data is presented in the manuscript and supplementary files.

Author contributions MSP and JK wrote the first draft of the paper; SS, IS, IG, MC reviewed the paper. All authors read and approved the final version of the manuscript before submission.

Open Access This article is licensed under a Creative Commons Attribution-NonCommercial 4.0 International License, which permits any non-commercial use, sharing, adaptation, distribution and reproduction in any medium or format, as long as you give appropriate credit to the original author(s) and the source, provide a link to the Creative Commons licence, and indicate if changes were made. The images or other third party material in this article are included in the article's Creative Commons licence, unless indicated otherwise in a credit line to the material. If material is not included in the article's Creative Commons licence and your intended use is not permitted by statutory regulation or exceeds the permitted use, you will need to obtain permission directly from the copyright holder. To view a copy of this licence, visit http://creativecommons.org/licenses/by-nc/4.0/.

\section{References}

1. Alum A, Rubino JR, Ijaz MK. The global war against intestinal parasites - should we use a holistic approach? Int J Infect Dis. 2010;14(9):e732-8.

2. Else KJ, Keiser J, Holland CV, Grencis RK, Sattelle DB, Fujiwara $\mathrm{RT}$, et al. Whipworm and roundworm infections. Nat Rev Dis Primers. 2020;6(1):44.

3. WHO. Guideline: preventive chemotherapy to control soil-transmitted helminth infections in at-risk population groups. Geneva: World Health Organization; 2017.

4. Montresor A, Trouleau W, Mupfasoni D, Bangert M, Joseph SA, Mikhailov A, et al. Preventive chemotherapy to control soil-transmitted helminthiasis averted more than 500,000 DALYs in 2015. Trans R Soc Trop Med Hyg. 2017;111(10):457-63.

5. Moser W, Schindler C, Keiser J. Efficacy of recommended drugs against soil transmitted helminths: systematic review and network meta-analysis. BMJ. 2017;358:j4307.

6. WHO. WHO Model list of essential medicines, 20th list. Geneva: World Health Organization; 2017. 
7. Olliaro P, Seiler J, Kuesel A, Horton J, Clark JN, Don R, et al. Potential drug development candidates for human soil-transmitted helminthiases. PLoS Negl Trop Dis. 2011;5(6):e1138.

8. Moser W, Schindler C, Keiser J. Drug combinations against soiltransmitted helminth infections. Adv Parasitol. 2019;103:91-115.

9. PubChem. Oxantel pamoate. 2005 cited. https://pubchem.ncbi. nlm.nih.gov/compound/5281086

10. Keiser J, Tritten L, Silbereisen A, Speich B, Adelfio R, Vargas M. Activity of oxantel pamoate monotherapy and combination chemotherapy against Trichuris muris and hookworms: revival of an old drug. PLoS Negl Trop Dis. 2013;7(3):e2119.

11. Keiser J, Häberli C. Evaluation of commercially available anthelminthics in laboratory models of human intestinal nematode infections. ACS Infect Dis. 2021. https://doi.org/10.1021/acsinfecdis. 0c00719.

12. Mackenzie CD. The safety of pyrantel, oxantel and morantel. In: Pryantel parasiticide therapy in humans and domestic animals. Elsevier; 2016. p. 47-66.

13. Lester RAJ. Nicotinic receptors. New York: Humana Press, Springer; 2014. p. 26.

14. Cowan N, Vargas M, Keiser J. In vitro and in vivo drug interaction study of two lead combinations, oxantel pamoate plus albendazole and albendazole plus mebendazole, for the treatment of soil-transmitted helminthiasis. Antimicrob Agents Chemother. 2016;60(10):6127-33.

15. Johnson \& Johnson. Rationale supporting the development of the 2018 Company Core Data Sheet for oral nonprescription oxantel pamoate, pyrantel pamoate products. 2018.

16. Neodo A, Schulz JD, Huwyler J, Keiser J. In vitro and in vivo drug-drug interaction study of the effects of ivermectin and oxantel pamoate on tribendimidine. Antimicrob Agents Chemother. 2019;63(1):e00762-e818.

17. Marchiondo AA. Pyrantel parasiticide therapy in humans and domestic animals. 1st ed. Academic Press; 2016.

18. Lim J. Anthelminthic effect of oxantel and oxantel-pyrantel in intestinal nematode infections. Drugs. 1978;15(1):99-103.

19. Barda B, Schindler C, Wampfler R, Ame S, Ali SM, Keiser J. Comparison of real-time PCR and the Kato-Katz method for the diagnosis of soil-transmitted helminthiasis and assessment of cure in a randomized controlled trial. BMC Microbiol. 2020;20(1):298.

20. Knopp S, Speich B, Hattendorf J, Rinaldi L, Mohammed KA, Khamis IS, et al. Diagnostic accuracy of Kato-Katz and FLOTAC for assessing anthelmintic drug efficacy. PLoS Negl Trop Dis. 2011;5(4):e1036.

21. Lim JK. Anthelminthic effect of oxantel pamoate against Tricocephalus trichiurus infection. Korean J Pharmacol. 1974;10(2):25-9.

22. Rim HJ, Won CY, Lee SI, Lim JK. Anthelmintic effect of oxantel pamoate and pyrantel pamoate suspension against intestinal nematode infestations. Korean J Parasitol. 1975;13(2):97-101.

23. Zaman V, Sabapathy NN. Clinical trial with a new anti-Trichuris drug, trans-1,4,5,6 tetrahydro-2-(3-hydroxystyryl)-1-methyl pyrimidine (CP-14,445). Southeast Asian J Trop Med Public Health. 1975;6(1):103-5.

24. Lee SH, Song CY, Lim JK. Anthelmintic effect of oxantel and oxantel/pyrantel tablets against intestinal nematode infections. Korean J Parasitol. 1977;15(2):121-6.

25. Lee SY, Lim JK. A comparative study of the effect of oxantelpyrantel suspension and mebendazole in mixed infections with Ascaris and Trichuris. Drugs. 1978;15(Suppl 1):94-8.

26. Garcia EG. Treatment of multiple intestinal helminthiasis with oxantel and pyrantel. Drugs. 1978;15(Suppl 1):70-2.

27. Dissanaike AS. A comparative trial of oxantel-pyrantel and mebendazole in multiple helminth infection in school children. Drugs. 1978;15(Suppl 1):73-7.
28. Rim HJ, Lee SH, Lee SI, Chang DS, Lim JK. Effect of oxantel/ pyrantel pamoate tablets against intestinal nematodes in Korea. Korean J Parasitol. 1978;16(1):14-20.

29. Cabrera BD, Sy FS. Oxantel-pyrantel in various regimens for the treatment of soil transmitted helminthiasis in rural and urban communities. Drugs. 1978;15(Suppl 1):78-86.

30. Choi WY, Lee OR, Lee WK, Kim WK, Chung CS, Ough BO. A clinical trial of oxantel and pyrantel against intestinal nematodes infections. Korean J Parasitol. 1979;17(1):60-6.

31. Cabrera BD, Cruz AC. Clinical trial of oxantel-pyrantel (quantrel) against trichuriasis. Acta Med Philipp. 1980;16(2):95-102.

32. Zahedi M, Oothuman P, Sabapathy NN, Bakar NA. Intestinal nematode infections and efficacy study of oxantel-pyrantel pamoate among plantation workers. Med J Malaysia. 1980;35(1):31-7.

33. Sinniah B, Sinniah D. The anthelmintic effects of pyrantel pamoate, oxantel-pyrantel pamoate, levamisole and mebendazole in the treatment of intestinal nematodes. Ann Trop Med Parasitol. 1981;75(3):315-21.

34. Rim HJ, Lee JS, Joo KH, Kim YS. Anthelmintic effects of single doses of fenbendazole and oxantel-pyrantel pamoate to the intestinal nematodes. Korean J Parasitol. 1981;19(2):95-100.

35. Peldán K, Pitkänen T. Treatment of Trichuris trichiura infection with a single dose of oxantel pamoate. Scand J Infect Dis. 1982;14(4):297-9.

36. Sinniah B. Intestinal protozoan and helminth infections and control of soil-transmitted helminths in Malay school children. Public Health. 1984;98(3):152-6.

37. Zu LQ, Jiang ZX, Yu SH, Ding XM, Bin XH, Yang HF, et al Treatment of soil-transmitted helminth infections by anthelmintics in current use. Chin J Parasitol. 1992;10(2):95-9.

38. Albonico M, Bickle Q, Haji HJ, Ramsan M, Khatib KJ, Montresor A, et al. Evaluation of the efficacy of pyrantel-oxantel for the treatment of soil-transmitted nematode infections. Trans Roy Soc Trop Med Hyg. 2002;96(6):685-90.

39. Speich B, Ame SM, Ali SM, Alles R, Huwyler J, Hattendorf J, et al. Oxantel pamoate-albendazole for Trichuris trichiura infection. N Engl J Med. 2014;370(7):610-20.

40. Speich B, Ali SM, Ame SM, Bogoch II, Alles R, Huwyler J, et al. Efficacy and safety of albendazole plus ivermectin, albendazole plus mebendazole, albendazole plus oxantel pamoate, and mebendazole alone against Trichuris trichiura and concomitant soil-transmitted helminth infections: a four-arm, randomised controlled trial. Lancet Infect Dis. 2015;15(3):277-84.

41. Moser W, Ali SM, Ame SM, Speich B, Puchkov M, Huwyler $\mathrm{J}$, et al. Efficacy and safety of oxantel pamoate in school-aged children infected with Trichuris trichiura on Pemba Island, Tanzania: a parallel, randomised, controlled, dose-ranging study. Lancet Infect Dis. 2016;16(1):53-60.

42. Moser W, Coulibaly JT, Ali SM, Ame SM, Amour AK, Yapi RB, et al. Efficacy and safety of tribendimidine, tribendimidine plus ivermectin, tribendimidine plus oxantel pamoate, and albendazole plus oxantel pamoate against hookworm and concomitant soiltransmitted helminth infections in Tanzania and Côte d'Ivoire: a randomised, controlled, single-blinded, non-inferiority trial. Lancet Infect Dis. 2017;17(11):1162-71.

43. Barda B, Ame SM, Ali SM, Albonico M, Puchkov M, Huwyler J, et al. Efficacy and tolerability of moxidectin alone and in co-administration with albendazole and tribendimidine versus albendazole plus oxantel pamoate against Trichuris trichiura infections: a randomised, non-inferiority, single-blind trial. Lancet Infect Dis. 2018;18(8):864-73.

44. Moser W, Sayasone S, Xayavong S, Bounheuang B, Puchkov M, Huwyler J, et al. Efficacy and tolerability of triple drug therapy with albendazole, pyrantel pamoate, and oxantel pamoate compared with albendazole plus oxantel pamoate, pyrantel pamoate plus oxantel pamoate, and mebendazole plus pyrantel pamoate and oxantel pamoate against hookworm infections in school-aged 
children in Laos: a randomised, single-blind trial. Lancet Infect Dis. 2018;18(7):729-37.

45. Lee EL, Iyngkaran N, Grieve AW, Robinson MJ, Dissanaike AS. Therapeutic evaluation of oxantel pamoate $(1,4,5,6$-tetrahydro-1-methyl-2-[trans-3-hydroxystyryl] pyrimidine pamoate) in severe Trichuris trichiura infection. Am J Trop Med Hyg. 1976;25(4):563-7.

46. Nicolas JM, Bouzom F, Hugues C, Ungell AL. Oral drug absorption in pediatrics: the intestinal wall, its developmental changes and current tools for predictions. Biopharm Drug Dispos. 2017;38(3):209-30.
47. Ofori-Adjei D, Dodoo ANO, Appiah-Danquah A, Couper M. A review of the safety of niclosamide, pyrantel, triclabendazole and oxamniquine. J Risk Saf Med. 2008;20(3):113-22.

48. Lloyd AE, Honey BL, John BM, Condren M. Treatment options and considerations for intestinal helminthic infections. J Pharm Technol. 2014;30(4):130-9.

49. Pfizer Venezuela SA. Oxantel pamoate, pyrantel pamoate insert; 2008. 